九州大学学術情報リポジトリ

Kyushu University Institutional Repository

\title{
Heavy Metal Pollution of Soils Along Three Major Highways in Bangladesh
}

Moslehuddin, Abu Zofar Md.

Laboratory of Soils, Faculty of Agriculture, Kyushu University

Laizoo, Salma

Laboratory of Soils, Faculty of Agriculture, Kyushu University

Egashira, Kazuhiko

Laboratory of Soils, Faculty of Agriculture, Kyushu University

https://doi.org/10.5109/24238

出版情報：九州大学大学院農学研究院紀要. 42 (3/4)，pp.503-508，1998-03. Kyushu University バージョン：

権利関係 : 


\title{
Heavy Metal Pollution of Soils Along Three Major Highways in Bangladesh
}

\author{
Abu Zofar Md. Moslehuddin, Salma Laizoo \\ and Kazuhiko Egashira \\ Laboratory of Soils, Faculty of Agriculture, \\ Kyushu University, Fukuoka 812-8581, Japan \\ (Received November 18, 1997 and accepted December 3, 1997)
}

\begin{abstract}
A study was carried out to investigate the heavy metal pollution of roadside soils by vehicles along three major highways in Bangladesh: Dhaka-Aricha, Dhaka-Chittagong and Dhaka-Mymensingh highways. Total contents of $\mathrm{Co}, \mathrm{Cr}, \mathrm{Cu}, \mathrm{Ni}, \mathrm{Pb}, \mathrm{Sr}$ and $\mathrm{Zn}$ were determined by the $\mathrm{HF}_{-} \mathrm{HNO}_{3}-\mathrm{HClO}_{4}$ acid treatment. Accumulation of $\mathrm{Pb}, \mathrm{Ni}, \mathrm{Cr}, \mathrm{Cu}$ and $\mathrm{Zn}$ in roadside soils along Dhaka-Mymensingh highway was observed, possibly due to the intensive traffic of vehicles. In addition, sporadic high $\mathrm{Zn}$ accumulation was noticed in soils along three highways which was ascribed to the industrial discharge.
\end{abstract}

\section{INTRODUCTION}

Pollution is now a global concern. With advancement of civilization, our beloved world becomes more and more polluted by various sources, rendering itself more and more hazardous for our life. Although extent of pollution is greater in developed countries, the condition of developing countries is not so safe. Rapid urbanization, industrialization, and motorization in many parts of Tropical Asia have considerably increased the risks of heavy metal pollution.

Bangladesh is an agro-based country; still there are some industries in and around the city area. Major cities are connected by roads and highways among themselves and with each corner of the country. The intensity of traffic in these roads specially near the cities is very high. Consequently, the possibility of soil pollution in nearby fields becomes large from the emission of fuel burning and addition from vehicle parts and tires. Such type of pollution has already been reported by many scientists (Page and Ganje, 1970; Tiller et al., 1987; Wheeler and Rolfe, 1979).

Research work on the heavy metal pollution of soils is highly limited in Bangladesh. Among the two major pollution sources, industries and vehicles, the present work was focused on the latter. To investigate heavy metal pollution by vehicles, soil samples from the vicinity of three major highways, which connect the capital Dhaka city with most parts of the country and have a very high intensity of buses, mini-buses, trucks etc., were collected and analyzed for heavy metals.

\section{MATERIALS AND METHODS}

\section{Soils used}

Ten soil samples were collected from each of Dhaka-Aricha (between Hemaetpur and 
Savar), Dhaka-Chittagong (between Kanchpur and Meghna) and Dhaka-Mymensingh (between Tongi and Joydevpur) highways. Of them, eight samples were taken from the roadside of the highway, while two were from the sites $1 \mathrm{~km}$ away from it, to be used as control samples. The sampling depth was $0-10 \mathrm{~cm}$. Brief description of soil samples is given in Table 1. Increase in the sample number in each highway indicates increase in the distance away from Dhaka city for Dhaka-Aricha highway, and the reverse for DhakaChittagong and Dhaka-Mymensingh highways.

The soil samples of each highway are not identical in physiography except for DhakaMymensingh highway, where all soil samples were taken from Madhupur Tract. In case of Dhaka-Aricha highway, seven soil samples were taken from Brahmaputra Floodplain while

Table 1. Brief description of soil samples.

\begin{tabular}{|c|c|c|c|}
\hline $\begin{array}{l}\text { Sample } \\
\text { No }\end{array}$ & Soil series & Physiography & Land use \\
\hline \multicolumn{4}{|c|}{ Dhaka-Aricha highway } \\
\hline 1 & $\begin{array}{l}\text { Brahmaputra } \\
\text { Silty Alluvium }\end{array}$ & Brahmaputra Floodplain & Boro-Fallow \\
\hline 2 & Melandaha & Brahmaputra Floodplain & Rabi vegetables-Sesbania-Fallow \\
\hline 3 & Dhamrai & Brahmaputra Floodplain & Boro-Jute-T. Aman \\
\hline 4 & Dhamrai & Brahmaputra Floodplain & Boro-Fallow \\
\hline 5 & Melandaha & Brahmaputra Floodplain & Rabi vegetables-Jute-Fallow \\
\hline 6 & Noadda & Madhupur Tract & Fallow \\
\hline 7 & Belabo & Madhupur Tract & Fallow \\
\hline $8^{*}$ & Melandaha & Brahmaputra Floodplain & Fallow \\
\hline 9 & Belabo & Madhupur Tract & Fallow \\
\hline $10^{*}$ & Melandaha & Brahmaputra Floodplain & Lentil-Jute-T. Aman \\
\hline \multicolumn{4}{|c|}{ Dhaka-Chittagong highway } \\
\hline 11 & Sonatala & Brahmaputra Floodplain & Rabi crops-Jute/B. Aman-Fallow \\
\hline 12 & Sonatala & Brahmaputra Floodplain & Boro-Fallow \\
\hline 13 & Jalkundi & Meghna Estuarine Floodplain & Mustard-Jute-Fallow \\
\hline 14 & Jalkundi & Meghna Estuarine Floodplain & Mustard-Boro-Fallow \\
\hline 15 & Jalkundi & Meghna Estuarine Floodplain & Mustard-Jute-Fallow \\
\hline $16^{*}$ & Jalkundi & Meghna Estuarine Floodplain & Mustard-Boro-Fallow \\
\hline 17 & Silmandi & Brahmaputra Floodplain & Mustard-Sesbania-Fallow \\
\hline 18 & Silmandi & Brahmaputra Floodplain & Fallow \\
\hline $19 *$ & Silmandi & Brahmaputra Floodplain & Mustard-Sesbania-Fallow \\
\hline 20 & Jalkundi & Meghna Estuarine Floodplain & Fallow \\
\hline \multicolumn{4}{|c|}{ Dhaka-Mymensingh highway } \\
\hline 21 & Demra & Madhupur Tract & Boro-Fallow-T. Aman \\
\hline $22 *$ & Chhiata & Madhupur Tract & Fallow-T. Aus-T. Aman \\
\hline 23 & Demra & Madhupur Tract & Fallow \\
\hline 24 & Demra & Madhupur Tract & Fallow \\
\hline $25 *$ & Chhiata & Madhupur Tract & Fallow-T. Aus-T. Aman \\
\hline 26 & Demra & Madhupur Tract & Fallow \\
\hline 27 & Khilgaon & Madhupur Tract & Fallow-T. Aman \\
\hline 28 & Demra & Madhupur Tract & Fallow \\
\hline 29 & Khilgaon & Madhupur Tract & Boro-T. Aman \\
\hline 30 & Kalma & Madhupur Tract & Boro-Fallow-T. Aman \\
\hline
\end{tabular}

* Control samples. 
the rest three from Madhupur Tract; in case of Dhaka-Chittagong highway, five from Brahmaputra Floodplain, and other five from Meghna Estuarine Floodplain (Table 1).

Collection and description of soil samples was performed by the staffs of Soil Resources Development Institute (SRDI), Krishi Khamar Sarak, Dhaka, as per request made by the authors. The soil samples, immediately after collection, were brought to Japan by air. They were then air-dried, gently crushed, passed through a 2 -mm sieve and kept in polyethylene bags for subsequent analysis.

\section{Analytical method}

Soil samples were digested with the $\mathrm{HF}-\mathrm{HNO}_{3}-\mathrm{HClO}_{4}$ acid treatment (Committee of Soil Standard Methods for Analyses and Measurements, 1986) to determine the total

Table 2. Total contents of heavy metals in roadside soils.

\begin{tabular}{|c|c|c|c|c|c|c|c|}
\hline \multirow{2}{*}{$\begin{array}{l}\text { Sample } \\
\text { No }\end{array}$} & $\mathrm{Co}$ & $\mathrm{Cr}$ & $\mathrm{Cu}$ & $\mathrm{Ni}$ & $\mathrm{Pb}$ & $\mathrm{Sr}$ & $\mathrm{Zn}$ \\
\hline & \multicolumn{7}{|c|}{$\left(\mathrm{mg} \mathrm{kg}{ }^{-1}\right)$} \\
\hline & \multicolumn{7}{|c|}{ Dhaka-Aricha highway } \\
\hline 1 & 16 & 92 & 47 & 53 & 27 & 147 & 125 \\
\hline 2 & 17 & 88 & 39 & 48 & 26 & 150 & 112 \\
\hline 3 & 17 & 93 & 43 & 45 & 28 & 140 & 80 \\
\hline 4 & 17 & 92 & 39 & 48 & 27 & 142 & 80 \\
\hline 5 & 16 & 80 & 34 & 40 & 23 & 160 & 144 \\
\hline 6 & 21 & 102 & 25 & 42 & 26 & 34 & 52 \\
\hline 7 & 13 & 71 & 16 & 23 & 20 & 34 & 51 \\
\hline $8^{*}$ & 22 & 91 & 33 & 37 & 32 & 138 & 501 \\
\hline 9 & 14 & 80 & 16 & 24 & 20 & 34 & 70 \\
\hline \multirow[t]{2}{*}{$10^{*}$} & 16 & 77 & 33 & 41 & 22 & 157 & 73 \\
\hline & \multicolumn{7}{|c|}{ Dhaka-Chittagong highway } \\
\hline 11 & 12 & 67 & 28 & 28 & 29 & 105 & 60 \\
\hline 12 & 15 & 90 & 36 & 44 & 27 & 126 & 74 \\
\hline 13 & 14 & 89 & 34 & 36 & 27 & 118 & 74 \\
\hline 14 & 16 & 94 & 37 & 44 & 28 & 114 & 85 \\
\hline 15 & 16 & 94 & 33 & 43 & 26 & 140 & 84 \\
\hline $16 *$ & 16 & 94 & 31 & 45 & 23 & 141 & 85 \\
\hline 17 & 15 & 88 & 29 & 42 & 25 & 137 & 80 \\
\hline 18 & 15 & 86 & 30 & 36 & 26 & 138 & 74 \\
\hline $19^{*}$ & 17 & 110 & 48 & 61 & 31 & 137 & 108 \\
\hline \multirow[t]{2}{*}{20} & 15 & 91 & 36 & 47 & 29 & 120 & 90 \\
\hline & \multicolumn{7}{|c|}{ Dhaka-Mymensingh highway } \\
\hline 21 & 14 & 85 & 27 & 31 & 24 & 50 & 72 \\
\hline $22 *$ & 11 & 65 & 16 & 20 & 17 & 46 & 27 \\
\hline 23 & 11 & 57 & 17 & 17 & 18 & 42 & 25 \\
\hline 24 & 12 & 70 & 25 & 22 & 23 & 76 & 88 \\
\hline $25^{*}$ & 11 & 61 & 17 & 19 & 19 & 68 & 155 \\
\hline 26 & 16 & 94 & 54 & 43 & 42 & 67 & 871 \\
\hline 27 & 22 & 126 & 38 & 54 & 33 & 44 & 73 \\
\hline 28 & 11 & 72 & 22 & 26 & 23 & 71 & 41 \\
\hline 29 & 20 & 109 & 35 & 54 & 29 & 61 & 59 \\
\hline 30 & 13 & 70 & 30 & 27 & 28 & 81 & 152 \\
\hline
\end{tabular}

* Control samples. 
contents of heavy metals. For this purpose, $1 \mathrm{~g}$ of powdered soil sample was weighed into a teflon beaker and placed on a hot plate. Five $\mathrm{mL}$ of $\mathrm{HClO}_{4}$ and $5 \mathrm{~mL}$ of $\mathrm{HNO}_{3}$ were added to the soil. The beaker was covered, heated for $2-3 \mathrm{~h}$ at $120^{\circ} \mathrm{C}$, and then heated without cover until dryness at $200^{\circ} \mathrm{C}$. After cooling and addition of $5 \mathrm{~mL} \mathrm{HClO}_{4}$ and $10 \mathrm{~mL}$ $\mathrm{HF}$ in this sequence, the beaker was heated at $80^{\circ} \mathrm{C}$ for $15 \mathrm{~min}$. It was cooled and again heated until dryness at $200^{\circ} \mathrm{C}$ after addition of another $10 \mathrm{~mL}$ of $\mathrm{HF}$. The beaker was cooled, $5 \mathrm{~mL}$ of $6 \mathrm{M} \mathrm{HCl}$ and $1 \mathrm{~mL}$ of $\mathrm{HNO}_{3}$ were added, and it was heated with cover at $100^{\circ} \mathrm{C}$ for about $1 \mathrm{~h}$. The beaker was then filled-up to its two-thirds with deionized water, covered and heated at $80^{\circ} \mathrm{C}$ for $2 \mathrm{~h}$. The solution was transferred into a $50 \mathrm{~mL}$ volumetric flask and made up to the mark with deionized water after cooling. The solution was quickly transferred into a plastic bottle and analyzed for $\mathrm{Cu}$ and $\mathrm{Pb}$ by atomic absorption spectrophotometer (AAS), and for $\mathrm{Co}, \mathrm{Cr}, \mathrm{Ni}, \mathrm{Sr}$ and $\mathrm{Zn}$ by inductively coupled plasmaatomic absorption spectrophotometer (ICP-AAS). The analytical results are shown in Table 2.

\section{RESULTS}

\section{Dhaka-Aricha highway}

Samples 6, 7 and 9 were taken from Madhupur Tract while others from Brahmaputra Floodplain, of which samples 8 and 10 are control samples.

Among the seven elements analyzed, total $\mathrm{Cu}$ and $\mathrm{Sr}$ contents showed a variation with physiography; soils of Brahmaputra Floodplain had higher values than did Madhupur Tract soils. Total Ni also showed the similar trend except for sample 6. Total $\mathrm{Pb}, \mathrm{Cr}$ and Co contents showed apparently no variation within ten samples. Only $\mathrm{Zn}$ gave an indication of soil pollution. Namely, sample 8 contained $501 \mathrm{mg} \mathrm{kg}^{-1}$ of total $\mathrm{Zn}$ which was much higher than the contents of other samples and even higher than the common range (10 to $300 \mathrm{mg} \mathrm{kg}^{-1}$ ) for soils as reported by Lindsay (1979). But, the cause of this

Table 3. The contents of various elements in the lithosphere and soils.

\begin{tabular}{lclrrrr}
\hline Element & $\begin{array}{l}\text { Content in } \\
\text { lithosphere } \\
\left(\mathrm{mg} \mathrm{kg}^{-1}\right)\end{array}$ & $\begin{array}{l}\text { Common } \\
\text { range } \\
\text { for soils } \\
\left(\mathrm{mg} \mathrm{kg}^{-1}\right)\end{array}$ & & \multicolumn{3}{c}{$\begin{array}{c}\text { Select average for soils } \\
\left(\mathrm{mg} \mathrm{kg}^{-1}\right)\end{array}$} \\
\cline { 4 - 7 } & & & & & & \\
\hline $\mathrm{Co}$ & 40 & $1-40$ & 8 & 9.1 & 58 & 56 \\
$\mathrm{Cr}$ & 200 & $1-1000$ & 100 & 54 & 133 & 136 \\
$\mathrm{Cu}$ & 70 & $2-100$ & 30 & 25 & 27 & 33 \\
$\mathrm{Ni}$ & 100 & $5-500$ & 40 & 19 & 22 & 22 \\
$\mathrm{~Pb}$ & 16 & $2-200$ & 10 & 19 & - & - \\
$\mathrm{Sr}$ & 150 & $50-1000$ & 200 & 240 & 66 & 108 \\
$\mathrm{Zn}$ & 80 & $10-300$ & 50 & 60 & 68 & 66 \\
\hline Reference & 1 & 2 & 3 & 4 & 5 & 6 \\
\hline
\end{tabular}

1, 2 and 3: Lindsay (1979); 4: Sposito (1989); 5: Domingo and Kyuma(1983) for Bangladesh paddy soils; and 6: Domingo and Kyuma (1983) for tropical Asian paddy soils. 
pollution is not considered to be due to vehicles, because the sample itself is a control one, collected $1 \mathrm{~km}$ away from the highway. Possible source of $\mathrm{Zn}$ pollution of sample 8 is discharge from some factories or industries nearby the sampling location. Samples 1,2 and 5 also contained the clearly high amounts of total $\mathrm{Zn}$ in comparison to the control sample (sample 10). The pollution in these soils again might be from some factories or industries.

\section{Dhaka-Chittagong highway}

Samples 11, 12 and 17 through 19 were taken from Brahmaputra Floodplain, while others from Meghna Estuarine Floodplain; samples 16 and 19 are control samples.

No variation according to physiography was noticed. Except for sample 19, the contents of different elements did not vary with the sample. Total $\mathrm{Zn}, \mathrm{Cr}, \mathrm{Ni}$ and $\mathrm{Cu}$ contents in sample 19 were higher than those in other samples. However, the reason is not due to the effects of vehicles as this sample is a control.

\section{Dhaka-Mymensingh highway}

All samples were collected from the same physiography of Madhupur Tract; samples 22 and 25 are control samples. Total Co and Sr contents did not vary among the samples. But other elements showed variation leading to possible trends of pollution.

According to Tiller (1989), $\mathrm{Pb}$ dominates the roadside environment because of its common use in a gasoline additive, lead tetraethyl. Other metals, especially $\mathrm{Cd}, \mathrm{Zn}, \mathrm{Cr}$ and $\mathrm{Ni}$, also accumulate near roads because of wear of vehicle parts and tires and use as fuel additives. From this viewpoint, $\mathrm{Pb}, \mathrm{Zn}, \mathrm{Cr}$ and $\mathrm{Ni}$ can be related to the pollution due to vehicles in our determination. Lead, $\mathrm{Cr}$ and Ni contents of samples 22 and 25, the control, were lower by 30 to $45 \%$ than those of seven samples (samples 21, 24 and 26 through 30 ), except for sample 23, collected from the roadside. Copper also showed the same tendency as $\mathrm{Pb}, \mathrm{Cr}$ and $\mathrm{Ni}$. These results probably indicate the $\mathrm{Pb}, \mathrm{Cr}, \mathrm{Ni}$ and $\mathrm{Cu}$ pollution of soils by vehicles along Dhaka-Mymensingh highway. Pollution of $\mathrm{Zn}$ by vehicles was also suggested, because total $\mathrm{Zn}$ content of sample 22 was lower than those of samples 21,24 and 26 through 30 . In addition to the pollution by vehicles, the extraordinarily high total $\mathrm{Zn}$ contents of samples 25, 26 and 30 indicate another source of pollution, probably discharge from some factories or industries. The $\mathrm{Zn}$ pollution by industrial discharge was most intensive for sample 26. The high total $\mathrm{Pb}$ and $\mathrm{Cu}$ contents of this sample compared to the other samples may be partially contributed by the industrial discharge.

\section{DISCUSSION}

Comparing the data of the present study with reported values listed in Table 3 , it is obvious that although total $\mathrm{Zn}, \mathrm{Pb}, \mathrm{Cu}, \mathrm{Ni}$ and $\mathrm{Cr}$ contents of soil samples were found to be higher than those of control samples, only Zn content in two samples (samples 8 and 26) was higher than the reported common range. This two soils can be termed as "polluted by Zn". Both soils were taken from fallow land (Table 1). It is also obvious from the present study that some other samples are accumulating $\mathrm{Zn}, \mathrm{Pb}, \mathrm{Cu}, \mathrm{Ni}$ and $\mathrm{Cr}$. Although these soils may not be termed as "polluted" at present, but may be so in near 
future. The reason for heavy metal accumulation, especially Zn, is apparently not the high density of vehicles; rather the effect of factories or industries around the sampling sites. However, for other metals as well as $\mathrm{Zn}$ in Dhaka-Mymensingh highway, vehicles can be considered as a reason.

It is not clear why the effect of traffic density on accumulation of heavy metals in nearby soils was not found in Dhaka-Aricha and Dhaka-Chittagong highways. One reason may be that the intensity of vehicles in these highways is lower than that of DhakaMymensingh highway; but apparently this is not true. Main contaminant from vehicles is $\mathrm{Pb}$ which is emitted mostly in fine particles and dispersed throughout large area (Tiller, 1989). This may be one possibility and sampling distance be another factor. Wheeler and Rolfe (1979) found that $\mathrm{Pb}$ in soil and vegetation decreased quickly with increasing distance from highway. The sampling distances from the road may be shorter in case of Dhaka-Mymensingh highway than those for the other two highways. Sampling depth also may be a factor. Further study should be done by reducing the sampling depth from $0-10 \mathrm{~cm}$ to $0-5$ or $0-1 \mathrm{~cm}$ and by taking sampling distance from the road as a variable.

\section{CONCLUSION}

Heavy metal pollution by factories and/or by vehicles was observed for soils along the three major highways in Bangladesh. Pollution of $\mathrm{Pb}, \mathrm{Ni}, \mathrm{Cr}, \mathrm{Cu}$ and $\mathrm{Zn}$ by vehicles was smaller in extent but prevailing in soils along the roadside in Dhaka-Mymensingh highway. Heavy metal pollution by factories or industries was mainly due to $\mathrm{Zn}$ and greater in extent but was site-specific.

\section{ACKNOWLEDGMENT}

We are greatly indebted to Mr. S. M. Saheed, Director, Soil Resources Development Institute (SRDI), Dhaka, Bangladesh and other staffs of the same organization for taking the trouble to collect and describe the soil samples used in this study.

\section{REFERENCES}

Committee of Soil Standard Methods for Analyses and Measurements (ed.) 1986 Soil Standard Methods for Analyses and Measurements. Hakuyusha, Tokyo (in Japanese)

Domingo, L. E. and K. Kyuma 1983 Trace elements in tropical Asian paddy soils. 1. Total trace element status. Soil Sci. Plant Nutr., 29: 439-452

Lindsay, W. L. 1979 Chemical Equilibria in Soils. Wiley-Interscience Publication, New York, pp. 6-8

Page, A. L. and T. J. Ganje 1970 Accumulation of lead in soils for regions of high and low traffic density, Environ. Sci. Technol., 4: 140-142

Sposito, G. 1989 The Chemistry of Soils. Oxford University Press, New York, pp. 3-7

Tiller, K.G. 1989 Heavy metal pollution in soils. Advan. Soil Sci, 9: 113-142

Tiller, K. G., L. H. Smith, R. H. Merry and P. M. Clayton 1987 The dispersal of automotive lead from metropolitan Adelaide into adjacent rural areas, Aust. J. Soil. Sci., 25: 155-166

Wheeler, G. L. and G. L. Rolfe 1979 The relationship between daily traffic volume and the distribution of lead in roadside soil and vegetation, Environ. Pollut. 18: 265-274 